\title{
The role of nanomaterials as effective adsorbents and their applications in wastewater treatment
}

\author{
Hamidreza Sadegh' ${ }^{1}$ Gomaa A. M. Ali Al,4 $^{2,}$ Vinod Kumar Gupta ${ }^{5}$. \\ Abdel Salam Hamdy Makhlouf ${ }^{6} \cdot$ Ramin Shahryari-ghoshekandi $^{1}$.

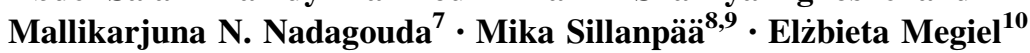

Received: 21 November 2016/Accepted: 10 January 2017/Published online: 28 January 2017

(c) The Author(s) 2017. This article is published with open access at Springerlink.com

\begin{abstract}
Nanomaterials have been extensively studied for heavy metal ions and dye removals from wastewater. This article reviews the role of nanomaterials as effective adsorbents for wastewater purification. In recent years, numerous novel nanomaterial adsorbents have been developed for enhancing the efficiency and adsorption capacities of removing contaminants from wastewater. The innovation, forthcoming development, and challenges of cost-effective and environmentally acceptable nanomaterials for water purification are discussed and reviewed in this article. This review concludes that nanomaterials have many unique morphological and structural properties that qualify them to be used as effective adsorbents to solve several environmental problems.
\end{abstract}

Hamidreza Sadegh

h.sadegh@chemist.com; hamidreza.sadegh@srbiau.ac.ir

$\bowtie$ Gomaa A. M. Ali

gomaasanad@azhar.edu.eg; gomaasanad@gmail.com

$\bowtie$ Vinod Kumar Gupta

vinodfcy@gmail.com

$\bowtie$ Mika Sillanpää

mika.sillanpaa@lut.fi

1 Department of Chemistry, Science and Research Branch, Islamic Azad University, Tehran, Iran

2 Chemistry Department, Faculty of Science, Al-Azhar University, Assiut 71524, Egypt

3 Al-Azhar Center of Nanoscience and Applications (ACNA), Al-Azhar University, Assiut 71524, Egypt

4 Faculty of Industrial Sciences and Technology, Universiti Malaysia Pahang, 26300 Gambang, Kuantan, Malaysia

\section{Graphical Abstract}

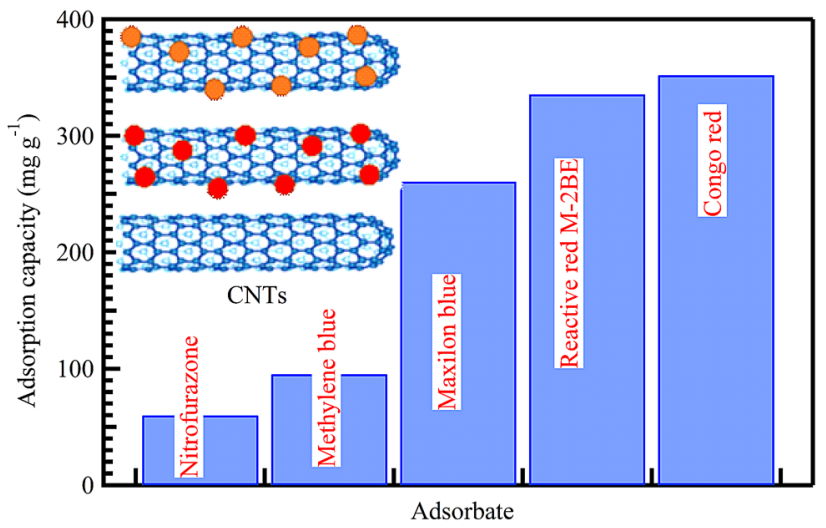

5 Department of Applied Chemistry, University of Johannesburg, Johannesburg, South Africa

6 Department of Manufacturing and Industrial Engineering, College of Engineering and Computer Science, University of Texas Rio Grande Valley, 1201 West University Dr., Edinburg, TX 78541-2999, USA

7 Department of Mechanical and Materials Engineering, Wright State University, Dayton, OH, USA

8 Laboratory of Green Chemistry, Lappeenranta University of Technology, Sammonkatu 12, FI-50130 Mikkeli, Finland

9 Department of Civil and Environmental Engineering, Florida International University, Miami, FL 33174, USA

10 University of Warsaw, Faculty of Chemistry, Pasteura 1, 02-093 Warsaw, Poland 
Keywords Nanomaterials · Heavy metal ions · Dyes . Adsorption - Wastewater treatment

\section{Introduction}

Treatment processes for wastewater as well as drinking water are one of the major prerequisites for developing, growing the economy as well as health maintaining. Therefore, it is crucial to develop and implement innovative technologies for treating water at high efficiencies and low energy consumption. On a global scale, waterborne diseases are still a major cause of death in developing countries where access to safe drinking water is often limited. With the introduction of disinfection processes (mainly using chlorine), waterborne infectious diseases have been significantly reduced. However, it is known that the application of disinfection agents such as chlorine, chlorine dioxide or ozone is associated with the formation of disinfection by-products (e.g., trihalomethanes, halophenols, ketones, aldehydes) with a high mutagenic and/or carcinogenic potential [1-4]. Chlorination also affects the taste and odor of drinking water. Therefore, the reduction/ elimination of toxic by-products formation resulting from disinfection processes is necessary. Further, many toxic materials such as heavy metal ions and azo dyes in wastewaters cannot be completely removed during wastewater treatment processes that are commonly used on a large scale [5-10]. Thus, these toxic materials are permanently introduced into rivers and streams by wastewater discharges, while diffuse sources such as runoff from agricultural fields are possible, but frequently contribute to a much smaller extent to the overall pollution [7, 11, 12].

The most common toxic materials in wastewaters responsible for particular problems are heavy metal ions and azo dyes [13-18]. Despite the fact that the human body needs low doses of metal ions such as for example $\mathrm{Zn}$ (II) ions, their excess may cause eminent health problems such as depression, lethargy, neurological signs and increased thirst. In addition, exposure to metal ions, often toxic, can cause health problems such as liver or kidney damage, Wilson disease, insomnia, cancer, diarrhea, nausea, vomiting, dermatitis, chronic asthma, coughing and headaches [19-21].

Removal of toxic materials from wastewater is necessary for health and environmental protection. For this purpose, conventional methods such as reduction, precipitation, adsorption, oxidation and ion exchange are commonly used. However, among them the adsorption process is the most suitable method because of its high efficiency and economic consideration [22-26]. Such adsorbents such as activated carbon (AC), zeolites, biomaterials, polymers, have been used extensively for wastewater treatment [22-31]. However, the adsorption efficiency of these materials is relatively low [26]. Therefore, it has become essential to find more efficient adsorbents.

Recently, there has been a remarkable potential for the remediation of environmental problems as a result of nanoscience and nanotechnology developments [32, 33]. In comparison to conventional materials, the nanostructured adsorbents, mainly due to the exceptionally high surface area, show much higher efficiencies and faster adsorption rates in water treatment [34-36]. A variety of efficient, lowcost and eco-friendly nanomaterials with unique functionalities have been proposed for potential applications in detoxification of industrial effluents, groundwater, surface water and drinking water [34, 37]. An ideal adsorbent for wastewater treatment purposes should satisfy the following criteria [26]: (1) should be environmentally benign; (2) should demonstrate a high sorption capacity and high selectivity especially to the pollutants occurring in water at low concentration; (3) the adsorbed pollutants can be easily removed from its surface, and (4) should be recyclable. In recent years, many studies have proved that the nanomaterials can satisfy most of these requirements [38-40].

It was demonstrated that the nanomaterials such as carbon nanotubes (CNTs), graphene, ferric oxide $\left(\mathrm{Fe}_{3} \mathrm{O}_{4}\right)$, manganese oxide $\left(\mathrm{MnO}_{2}\right)$, titanium oxide $\left(\mathrm{TiO}_{2}\right)$, magnesium oxide $(\mathrm{MgO})$ and zinc oxide $(\mathrm{ZnO})$ may play an important role in the waste water treatment processes [41-49]. The nanomaterials may be successfully used as efficient, cost-effective and environmentally friendly adsorbents for the removal of various toxic substrates from wastewater such as heavy metals, azo dyes, etc. [2, 5-9, 34, 37-46, 49-51].

\section{Adsorption phenomenon}

The adsorption process is a surface phenomenon in which the adsorbate is accumulated on the adsorbent surface. When a solution containing absorbable solute comes into contact with a solid with a highly porous surface structure, liquid-solid intermolecular forces of attraction cause some of the solute molecules from the solution to be concentrated or deposited on the solid surface [46-48]. In case of bulk materials, all the bonding requirements (ionic, covalent, or metallic) of the material constituent atoms are filled by other atoms in the material. However, the atoms on the surface of the adsorbent are not wholly surrounded by other adsorbent atoms, therefore they can attract adsorbates [48-52]. The exact nature of the bonding depends on the details of the species involved, but the adsorption process is generally classified as physisorption (an adsorbate bound to the surface by weak van der Waals forces), chemisorption (an adsorbate tethered through covalent bonding [53] or due to electrostatic attraction [26]). 
The equilibrium stage of adsorption between the solution and adsorbent is attained (where the adsorption of solute from the bulk onto the adsorbent is minimum) and the adsorption amount $\left(q_{\mathrm{e}}, \mathrm{mmol} \mathrm{g}^{-1}\right)$ of the molecules at the equilibrium could be calculated according to the following equation $[48,53]$ :

$q_{\mathrm{e}}=\frac{V\left(C_{0}-C_{\mathrm{e}}\right)}{m}$,

where $V$ is the solution volume (L); $m$ is the mass of adsorbents $(\mathrm{g})$; and $C_{0}$ and $C_{\mathrm{e}}$ are the initial and equilibrium adsorbate concentrations, respectively. In addition, adsorption maybe defined as the mass transfer process by which a substance is transferred from the liquid phase to the surface of a solid, and becomes bound by physical and/ or chemical interactions [54]. It is worth pointing out that the large surface area of adsorbent allows achieving a high adsorption capacity and surface reactivity [54].

\section{Adsorption isotherm models}

The adsorption isotherm models present of the amount of solute adsorbed per unit weight of adsorbent as a function of the equilibrium concentration in the bulk solution at constant temperature [52, 54-56]. There are many isotherm models such as: Langmuir and Freundlich, Temkin, Harkin-Jura and Dubinin-Radushkevich. Among of them, Langmuir and Freundlich models are commonly used for the description of adsorption data [48, 55-57].

The Langmuir equation is expressed as $[48,56]$ :

$\frac{C_{\mathrm{e}}}{q_{\mathrm{e}}}=\frac{1}{Q_{\max } K_{1}}+\left(\frac{1}{Q_{\max }}\right) C_{\mathrm{e}}$,

where $C_{\mathrm{e}}$ is the equilibrium concentration $\left(\mathrm{mg} \mathrm{L}^{-1}\right), q_{\mathrm{e}}$ is the amount of adsorbate adsorbed per unit mass of adsorbent $\left(\mathrm{mg} \mathrm{g}^{-1}\right)$, and $Q_{\max }$ and $K_{1}$ are Langmuir constants related to monolayer adsorption capacity and affinity of adsorbent toward adsorbate, respectively.

On the other hand, Freundlich isotherm describes heterogeneous surface adsorption. The energy distribution for adsorptive sites (in Freundlich isotherm) follows an exponential type function which is close to the real situation. The rate of adsorption/desorption varies with the strength of the energy at the adsorptive sites. The Freundlich equation is expressed as [48]:

$\log q_{\mathrm{e}}=\log K_{\mathrm{F}}+\frac{1}{n} \log C_{\mathrm{e}}$,

where $k\left(\mathrm{mg} \mathrm{g}^{-1}\right)$ and $1 / n$ are the constant characteristics of the system $[56,58]$. An example of the linear relation of Freundlich and Langmuir isotherms is displayed in Fig. 1 for $\mathrm{MB}$ adsorption on $\mathrm{Co}_{3} \mathrm{O}_{4} / \mathrm{SiO}_{2}$ nanocomposites [57].

\section{Kinetic models}

An applicable kinetic model is necessary to analyze the rate and the mechanism of adsorption processes (e.g., mass transfer and chemical reaction). Several kinetic models such as simple-first-order, pseudo-first-order, pseudo-second-order and intra-particle diffusion models $[48,53,57,59,60]$ have been applied to disclose the adsorbate-adsorption phenomenon.

The simple-first-order and pseudo-first-order rate equations are given by Eqs. (4) and (5), respectively [48, 56, 57]:

$\log q_{t}=\frac{k_{s}}{2.303} t+\log q_{\mathrm{e}}$

$\log \left(q_{\mathrm{e}}-q_{t}\right)=\log q_{\mathrm{e}}-\frac{k_{1}}{2.303} t$,

where $q_{\mathrm{e}}$ and $q_{t}$ are the amounts of adsorbate $\left(\mathrm{mg} \mathrm{g}^{-1}\right)$ at equilibrium and at time $t$, respectively. $k_{s}$ and $k_{1}$ are the rate constants $\left(\mathrm{h}^{-1}\right)$.
Fig. 1 Freundlich (left) and Langmuir (right) isotherms for $\mathrm{MB}$ adsorption on $\mathrm{Co}_{3} \mathrm{O}_{4} / \mathrm{SiO}_{2}$ nanocomposite, The solid lines are the linear fits (copied form Ref. [57])
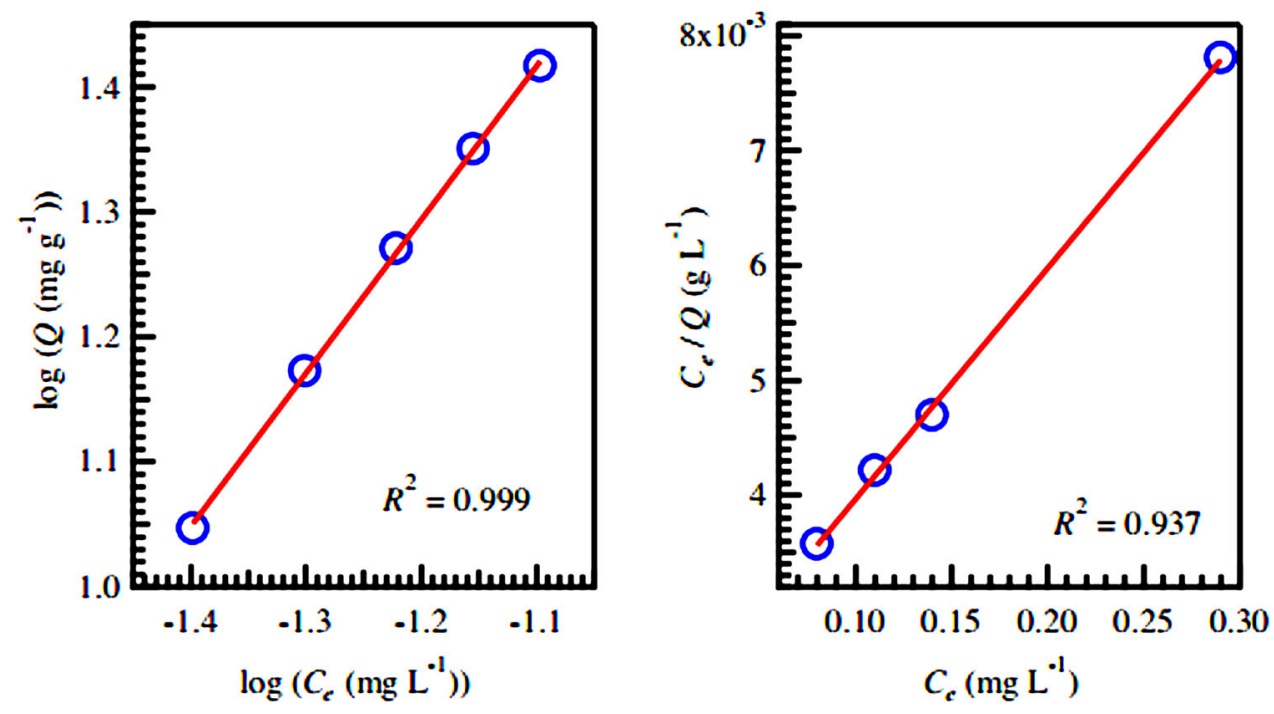
On the other hand, the pseudo-second-order rate formula is as following $[48,56,57,60]$ :

$\frac{t}{q_{t}}=\frac{1}{k_{2} q_{\mathrm{e}}^{2}}+\frac{1}{q_{\mathrm{e}}} t$

where $k_{2}$ is the equilibrium rate constant $\left(\mathrm{g} \mathrm{mg}^{-1} \mathrm{~h}^{-1}\right)$. The slopes and intercepts $t / q$ versus $t$ plot are used to calculate $k_{2}$.

In addition, intraparticle diffusion model which can be described as follows [56, 57]:

$q_{t}=k_{\mathrm{p}} t^{1 / 2}+C$

where $C$ is the intercept and $k_{\mathrm{p}}$ is the intra-particle-diffusion rate constant $\left(\mathrm{mg} \mathrm{g}^{-1} \mathrm{~h}^{1 / 2}\right)$, which can be evaluated from the slope of the linear plot of $q_{t}$ versus $t^{1 / 2}$.

\section{Development of nanomaterials as adsorbent for wastewater treatment}

The most widely studied nanomaterials for wastewater treatment are $\mathrm{AC}, \mathrm{CNTs}$, graphene, $\mathrm{Fe}_{3} \mathrm{O}_{4}, \mathrm{MnO}_{2}, \mathrm{Co}_{3} \mathrm{O}_{4}$, $\mathrm{TiO}_{2}, \mathrm{MgO}$ and $\mathrm{ZnO}$, etc. [22, 43, 46, 52, 57, 61-68]. They may be prepared in different morphological forms such as particles, tubes and sheets [26].

Hereby we review recent advances in heavy metals and dye removal from wastewater using nanomaterials as effective adsorbents and perspectives in this area of research.

\section{Carbon-based nanomaterials}

Different types of carbon-based nanomaterials have been used widely for heavy metals and dye removal in recent decades due to their nontoxicity, abundance, ease of preparation, high surface area and porosity, stable structure and high sorption capacities [38, 41, 52, 69-71].

\section{Activated carbon (AC)}

AC was used initially as sorbents; however, due to the difficulties associated with heavy metals and dye removal at ppb levels, CNTs, fullerenes, and graphene were used as nanosorbents to overcome this difficulty. AC typically has high porosity, high surface area, and can be prepared from readily available carbonaceous precursors such as coal, wood, coconut shells and agricultural wastes [72-75]. AC is extensively used for the removal of inorganic and organic pollutants from effluent streams and in water treatment [22]. In addition, it possesses a significantly weak acidic ion exchange character, enabling it to remove metal contaminants and to adsorb pollutants from wastewater [22]. The sorption of pentavalent arsenic on granular activated carbon (GAC) was experimentally studied [75]. AC prepared from coconut tree sawdust was used as an adsorbent for the removal of $\mathrm{Cr}(\mathrm{VI})$ from aqueous solution [76]. Sorption and stability of mercury on AC for emission control were also reported [72]. Powdered activated carbon (PAC) prepared from Eucalyptus camaldulensis Dehn bark was studied and showed a sorption capacities $\left(q_{m}\right)$ at $60{ }^{\circ} \mathrm{C}$, of 0.85 and $0.89 \mathrm{mmol} \mathrm{g}^{-1}$ for $\mathrm{Cu}$ (II) and $\mathrm{Pb}(\mathrm{II})$, respectively [73]. A novel sodium polyacrylate grafted AC was produced using gamma radiation to increase the number of functional groups on the surface which increased the efficiency of metal ions sorption by AC [74]. Their high sorption ability and low price make AC promising materials for heavy metals and dye removal.

\section{Carbon nanotubes (CNTs)}

CNTs (Fig. 2), which were first developed by Iijima [77], have a unique structural, electronic, optoelectronic, and semiconductor, as well as mechanical, chemical and physical properties [22, 23]. CNTs have been applied widely to remove heavy metals and dyes in wastewater treatment $[6,7,9,11-16,41,71,78-82]$.

CNTs are considered to be one of the most promising adsorbents for wastewater treatment because of their large adsorption capacity for synthetic dyes [15]. Multi-walled carbon nanotubes (MWCNTs) have been shown to surpass cadmium hydroxide nanowire-loaded $\mathrm{AC}\left(\mathrm{Cd}(\mathrm{OH})_{2}-\mathrm{NW}-\right.$ $\mathrm{AC}$ ) with respect to their efficient removal of safranin $\mathrm{O}$ (SO) from wastewater [83]. However, only few studies were reported on the application of CNTs for dye removal from aqueous solution [41, 69, 76, 84-86]. Moreover, CNTs were typically used directly without further treatment [41, 69, 85]. Therefore, CNT functionalization has been initiated to introduce various functional groups that provide new adsorption sites [15]. Among such modifications, oxidation is an easy method for introducing hydroxyl and carbonyl groups to the sidewalls of CNTs. Oxidized MWCNTs were found to be effective in the removal of methylene red (MR) and methylene blue (MB) from aqueous solutions [87, 88]. Yao et al. [89] reported an adsorption capacity of $41.63 \mathrm{mg} \mathrm{g}^{-1}$ at $333 \mathrm{~K}$ for the removal of MB onto CNTs. Shahryari et al. [90] performed the same batch of experiments on MWCNTs having a higher surface area of $280 \mathrm{~m}^{2} \mathrm{~g}^{-1}$ as compared to that of CNTs $\left(160 \mathrm{~m}^{2} \mathrm{~g}^{-1}\right)$ used by Yao et al. and reported a higher $\mathrm{MB}$ adsorption of $132.6 \mathrm{mg} \mathrm{g}^{-1}$ at $310 \mathrm{~K}$. In addition, cellulose grafted with soy protein isolate/hydroxyapatite rod-like nanocrystals showed a high MB adsorption capacity of $454 \mathrm{mg} \mathrm{g}^{-1}$ [91]. 
Fig. 2 Schematics of SWCNTs (a) and MWCNTs (b) (copied form Ref. [22]) (a)

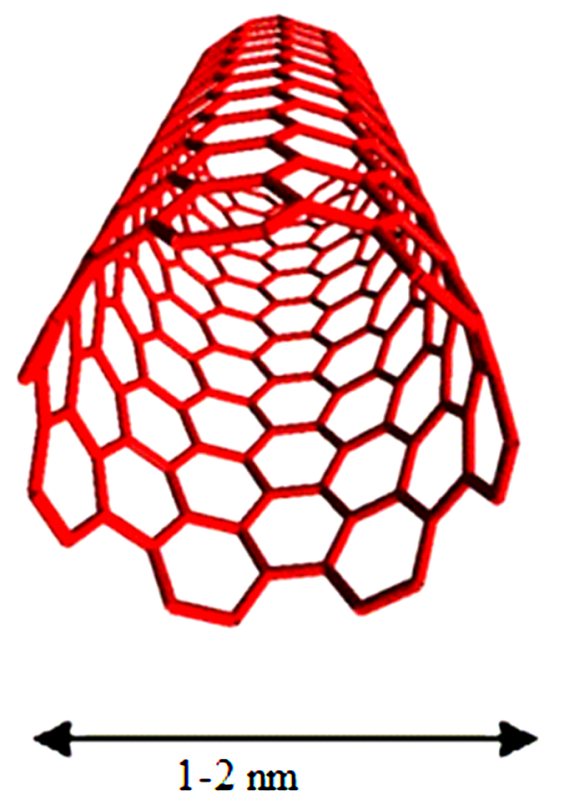

(b)

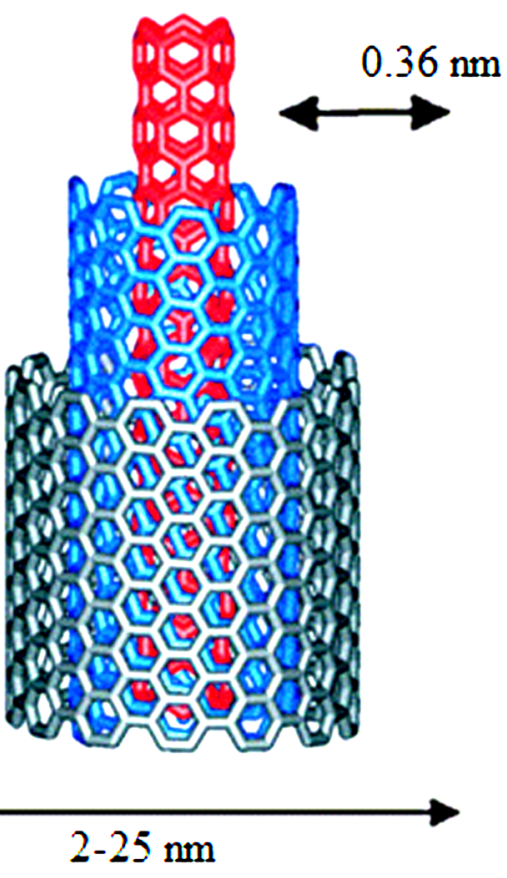

The adsorption capacity also depends on the experimental conditions, nature and type of adsorbent. The comparative adsorption of anionic orange II (OII) from aqueous solution using MWNTs and carbon nanofibers (CNF) as adsorbents was studied in batch experiments by Rodríguez et al. [75]. They found that the adsorption of II (OII) onto MWCNTs was slightly higher than CNF (the adsorption capacity in case of MWCNTs was $77.83 \mathrm{mg} \mathrm{g}^{-1}$, while it was $66.12 \mathrm{mg} \mathrm{g}^{-1}$ in case of CNF [75]). In addition, MWCNTs showed higher adsorption than PAC for removal of reactive red M-2BE (RRM). The maximum amounts of RRM uptake were 335.7 and $260.7 \mathrm{mg} \mathrm{g}^{-1}$ for MWCNTs and PAC, respectively [76]. The higher adsorption capacity can be explained on the basis of higher average pore diameter of MWCNTs, which was $7.62 \mathrm{~nm}$ as compared to $3.52 \mathrm{~nm}$ of PAC. It seems that dye molecules can easily be diffused from the surface to pores of MWCNTs due to larger pore size.

CNT-impregnated chitosan hydrogel beads (CSBs) have been developed for the removal of congo red (CR). CSBs demonstrated a higher maximum adsorption capacity (450.4 $\mathrm{mg} \mathrm{g}^{-1}$ ) than chitosan without impregnation (200 $\mathrm{mg} \mathrm{g}^{-1}$ ) based on Langmuir adsorption modeling [72]. A new generation of CSBs has been prepared by sodium dodecyl sulfate and MWCNTs to improve the mechanical properties [73]. The new CSBs have demonstrated a high maximum adsorption capacity for CR of $375.94 \mathrm{mg} \mathrm{g}^{-1}$ [73]. Compared to MWCNTs and hybrid CNTs (HCNTs), single wall carbon nanotubes (SWCNTs) can demonstrate better adsorption properties for organic contaminants because of their higher specific surface area. SWCNTs are more efficient for removing benzene and toluene and have shown maximum adsorption capacities of 9.98 and $9.96 \mathrm{mg} \mathrm{g}^{-1}$, respectively [74]. A maximum adsorption capacity of $496 \mathrm{mg} \mathrm{g}^{-1}$ was achieved when a reactive blue 29 (RB29) has been removed from aqueous solution by using SWCNTs [92].

On the other hand, CNTs showed high sorption efficiency of divalent metal ions. The advantages and drawbacks of $\mathrm{Co}$ (II) and $\mathrm{Cu}$ (II) removal using AC, CNTs, and carbon-encapsulated magnetic nanoparticles were reported by Pyrzyńska and Bystrzejewski [80]. The results showed that the carbon nanomaterials have significantly higher sorption efficiency compared to commercial AC. Meanwhile, Stafiej and Pyrzynska [79] found out that the solution conditions such as $\mathrm{pH}$ and metal ion concentrations could affect the adsorption characteristics of CNTs. Oxidized CNTs have also shown exceptionally high sorption capacity and efficiency for $\mathrm{Pb}$ (II), $\mathrm{Cd}$ (II) and $\mathrm{Cr}$ (VI) from water [78, 93, 94]. CNTs were also reported as good adsorbents for multi-component sorption of metal ions [71]. The sorption mechanisms were reported to be governed by the surface features, ion exchange process and electrochemical potential [95]. The latter plays a significant role in multi-component sorption where redox reactions, not only on the adsorbent surface but also among the different adsorbates, are likely to occur. MWCNTs were found to adsorb ${ }^{243} \mathrm{Am}$ with extraordinarily high efficiency by forming very stable complexes [96]. The sorption characteristic of $\mathrm{Pb}$ (II) from aqueous solution was studied using oxidized MWCNTs [81]. The reported results showed a slope of $\mathrm{V} / \mathrm{m}$ and intercept of $C_{o} \mathrm{~V} / \mathrm{m}$ for the same initial concentration of $\mathrm{Pb}$ (II) and the same content of oxidized MWCNTs for each experimental data [81]. 
Fig. 3 Schematics structure of graphene (a) and graphene oxide (b) (copied form Ref. [57]) (a)

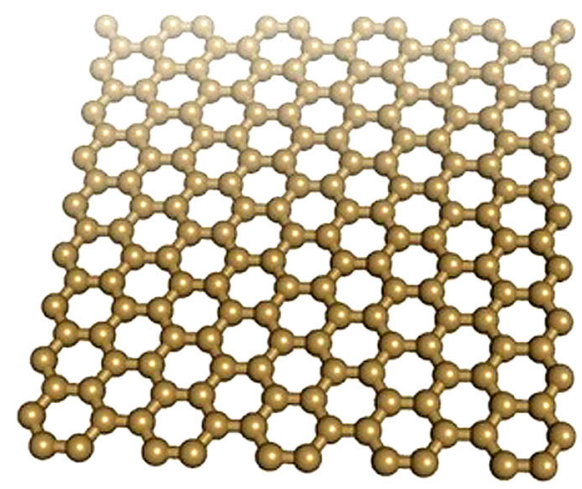

(b)

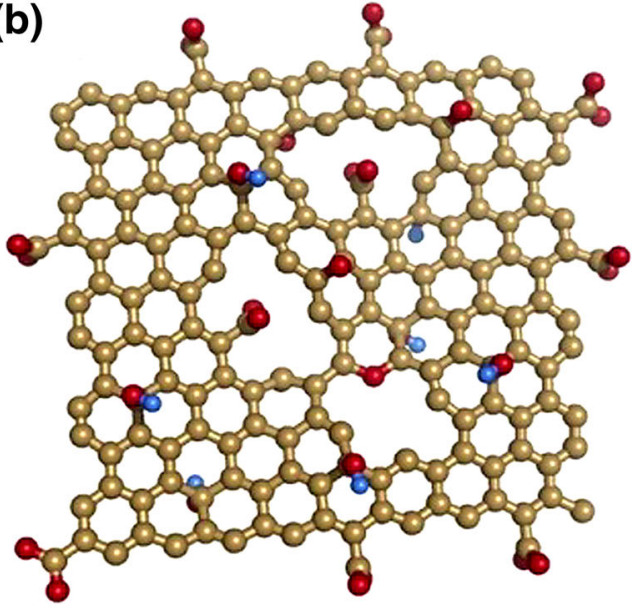

Oxidized MWCNTs were also applied to adsorb Ni(II) from aqueous solution [41]. The predominant mechanism of $\mathrm{Ni}(\mathrm{II})$ sorption onto MWCNTs was reported to be ion exchanged at low $\mathrm{pH}$ values and by strong surface complexation at high $\mathrm{pH}$ values [41]. It was also reported that oxidized MWCNTs can be potentially promising materials for the pre-concentration and solidification of heavy metal ions [70].

The sorption and kinetic desorption of ${ }^{152+154} \mathrm{Eu}$ (III) on MWCNTs have also been studied [97]. It was found that MWCNTs were a suitable material for pre-concentration of lanthanides from large volumes of aqueous solutions in radioactive nuclear waste management with the strong surface complexation and/or chemisorption mechanism [97]. With the aid of FITEQL 3.2, Chen et al. [82] characterized the surface properties of MWCNTs at different ionic strengths and $\mathrm{pH}$ values, and modeled $\mathrm{Sr}(\mathrm{II})$ and $\mathrm{Eu}(\mathrm{III})$ sorption onto oxidized MWCNTs by applying surface complexation model, and found that the diffuse layer model (DLM) fit the experimental data very well. The removal of divalent metal ions [Cd(II), $\mathrm{Cu}(\mathrm{II}), \mathrm{Ni}(\mathrm{II})$, $\mathrm{Pb}(\mathrm{II}), \mathrm{Zn}(\mathrm{II})]$ from aqueous solution using various kinds of CNTs have been studied [98]. It has been proved that the CNTs are very promising adsorbents for environmental protection applications because of their superior sorption capacity and in the same time ability to effective desorption of divalent metal ions [98].

It is worth noting that the CNTs can be potentially produced on a large scale using different methods such as chemical vapor deposition to reduce the cost of production and increase their future use in environmental protection applications.

\section{Graphene}

Graphene (Fig. 3), which can be used as nanosorbents, typically consists of one or more atomic-layered carbon

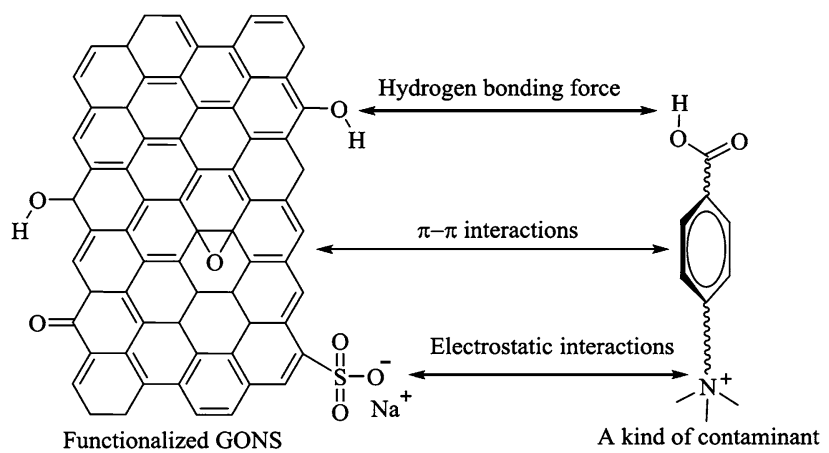

Fig. 4 Schematic representation of possible interactions between GONSs and pollutants (copied form Ref. [110])

atoms, and possesses a unique two-dimensional structure and excellent mechanical, thermal and electrical properties $[99,100]$. Using Van der Waals' forces and $\pi-\pi$ stacking interactions, the adsorption of dyes on few-layered graphene nanosheets can be realized (see Fig. 4). For modify the chemical and physical properties and improve the manufacturing of reduced graphene oxide (rGONSs) graphene oxide nanosheets (GONSs), it can be first incorporated into composite materials. Both rGONSs layers and single GONSs layers have high aspect ratios and large $\pi$ electronic surfaces that provide strong intermolecular forces among adsorbates [101]. Due to the opened-up layer structure, rGONSs exhibit markedly faster adsorption kinetics than CNTs [63, 102]. Among different carbonbased materials (coal base AC (HD4000), SWCNTs and MWCNTs), rGONSs exhibited better adsorption capacities for two synthetic organic compounds (SOCs; phenanthrene and biphenyl) in aqueous solutions [52]. More importantly, rGONSs are much cheaper than SWCNTs [103]. rGONSs have already been used as adsorbents for the removal of cationic red X-GRL [104], MB [66, 105], methyl orange (MO) [106], CR [107] and other organic materials from aqueous solutions. The maximum adsorption capacities of 
p-toluenesulfonic acid ( $p$-TA), 1-naphthalenesulfonic acid (1-NA) and MB on GNS reach up to 1430, 1460 and $1520 \mathrm{mg} \mathrm{g}^{-1}$ at $303 \mathrm{~K}$, respectively, which are the highest among all nanomaterials studied in this field to date [108]. The observed adsorption capacities for the adsorption of three types of pesticides [chlorpyrifos (CP), endosulfan (ES), and malathion (ML)] onto GONSs and rGONSs from water are as high as 1200,1100 and $800 \mathrm{mg} \mathrm{g}^{-1}$, respectively, and GONSs and rGONSs were unprecedented substrates for these adsorption technologies [109].

The few-layered GONSs through the modified Hummers' method have been synthesized [111]. These rGONSs can be used as sorbents for the removal of $\mathrm{Cd}(\mathrm{II})$ and $\mathrm{Co}$ (II) ions from aqueous solution [111]. It was reported that heavy metal ions sorption on nanosheets is dependent on $\mathrm{pH}$ and ionic strength [111]. The abundant oxygencontaining functional groups on the surfaces of graphene oxide nanosheets were reported to play an important role on sorption [111].

Magnetite-graphene composite adsorbent with a particle size of $\sim 10 \mathrm{~nm}$ was reported to give a high binding capacity for $\mathrm{As}(\mathrm{III})$ and As(V) [112]. The high binding capacity was due to the increased adsorption sites in the graphene composite [112]. The strong functional groups on the graphene oxide (GO) surface make it a potential adsorbent for metal ion complexation through both electrostatic and coordinate approaches. Generally, GO showed high adsorption capacity for cationic metals. rGONSs can be used for adsorption of both cationic and anionic metals. After modification of GO with organics or metal oxides, its composites can also be used for anionic metal removal due to functionalization. $\mathrm{Cu}(\mathrm{II})-\mathrm{GO}$ interaction in aqueous solution showed that $\mathrm{Cu}$ (II) causes GO sheets to be folded and form large aggregates [113]. The coordination between $\mathrm{Cu}(\mathrm{II})$ and oxygen atoms on GO was the primary driving force. $\mathrm{GO}$ has a $\mathrm{Cu}$ (II) adsorption capacity of $46.6 \mathrm{mg} \mathrm{g}^{-1}$, which is higher than that of CNTs $\left(28.5 \mathrm{mg} \mathrm{g}^{-1}\right)$ and AC (4-5 $\mathrm{mg} \mathrm{g}^{-1}$ ) [113].

The removal of $\mathrm{Cd}(\mathrm{II})$ [71, 111], $\mathrm{Co}(\mathrm{II})$ [111], $\mathrm{Pb}$ (II) [71, 114], and U(VI) [115] ions from aqueous solutions have been studied using few-layered GONSs. It was found that the abundant oxygen-containing functional groups on GONSs surfaces play an important role in metal sorption, which was in agreement with the results of Zhao et al. [111]. It was also reported that $\mathrm{Cd}(\mathrm{II})$ and $\mathrm{Co}(\mathrm{II})$ sorption on GONSs is strongly dependent on $\mathrm{pH}$ and weakly dependent on ionic strength. The presence of humic acid reduced $\mathrm{Cd}(\mathrm{II})$ and $\mathrm{Co}(\mathrm{II})$ sorption on GONSs at $\mathrm{pH}<8$. The maximum sorption capacities of $\mathrm{Cd}(\mathrm{II})$ and $\mathrm{Co}(\mathrm{II})$ on GONSs at $\mathrm{pH} 6.0$ and $303 \mathrm{~K}$ were about 106.3 and $68.2 \mathrm{mg} \mathrm{g}^{-1}$, respectively. For $\mathrm{Pb}(\mathrm{II})$, the maximum adsorption capacities were about 842, 1150, and $1850 \mathrm{mg} \mathrm{g}^{-1}$ at 293, 313, and $333 \mathrm{~K}$, respectively [114], but sorption capacity of $\mathrm{U}(\mathrm{VI})$ at $\mathrm{pH} 5.0,293 \mathrm{~K}$ was $97.5 \mathrm{mg} \mathrm{g}^{-1}$ [115].

Modification of GO with organic materials can change the surface functional groups for better adsorption of various metal ion species. A modified GO with thiol ( $\mathrm{SH}$ ) groups by diazonium chemistry was reported to adsorb sixfold higher concentration of $\mathrm{Hg}(\mathrm{II})$ ions than GO and AC [116]. When $N$-(trimethoxysilylpropyl) ethylenediaminetriacetic acid (EDTA-silane) was used to obtain a chelating GO for $\mathrm{Pb}(\mathrm{II})$ removal, the adsorption was fast and completed within $20 \mathrm{~min}$, with an adsorption capacity of $479 \mathrm{mg} \mathrm{g}^{-1}$ at $\mathrm{pH}$ 6.8 [117]. Compared to AC and CNTs, GO and GNs present stronger adsorption for many water pollutants.

\section{Metal oxide-based nanomaterials}

Metal or metal oxide-based nanomaterials are other inorganic nanomaterials, which are widely used to remove heavy metal ions and dyes. Nanosized metals or metal oxides, including $\mathrm{Fe}_{3} \mathrm{O}_{4}$ [118], $\mathrm{MnO}_{2}$ [62], $\mathrm{TiO}_{2}$ [43], $\mathrm{MgO}$ [119], $\mathrm{CdO}$ [120] and $\mathrm{ZnO}$ [68], provide high surface area and specific affinity. Metal oxides possess minimal environmental impact, low solubility, and are not involved in secondary pollution formation; they have also been adopted as sorbents to remove heavy metals and dyes.

Iron is one of the most widespread elements in the earth. The facileness of resource and ease of synthesis render nanosized ferric oxides to be low-cost adsorbents for toxic metal sorption. Since elemental iron is environmentally friendly, nanosized ferric oxides can be pumped directly to contaminated sites with negligible risks of secondary contamination [121, 122]. Many reports discussed the influence of different parameters on the removal of metal ions by $\mathrm{Fe}_{3} \mathrm{O}_{4}$ magnetic nanoparticles [47, 123]. For example, the adsorption efficiency of $\mathrm{Ni}(\mathrm{II}), \mathrm{Cu}(\mathrm{II}), \mathrm{Cd}(\mathrm{II})$ and $\mathrm{Cr}(\mathrm{VI})$ ions by $\mathrm{Fe}_{3} \mathrm{O}_{4}$ nanoparticles was strongly dependent on $\mathrm{pH}$, temperature, amount of the adsorbent and the incubation time [124-127]. Further, a higher removal efficiency of these metal ions at a $3.5 \mathrm{mg} \mathrm{mL}^{-1}$ dose of nanoadsorbent with an optimum $\mathrm{pH}$ of 4 was obtained. In comparison to bare $\mathrm{Fe}_{3} \mathrm{O}_{4}$ nanoparticles, surface functionalized $\mathrm{Fe}_{3} \mathrm{O}_{4}$ nanoparticles have been extensively used for the removal of toxic metal ions [124-127]. Singh et al. [46] reported the removal of toxic metal ions from wastewater using carboxyl-, amine- and thiol-functionalized $\mathrm{Fe}_{3} \mathrm{O}_{4}$ nanoparticles (succinic acid, ethylenediamine and 2,3-dimercaptosuccinic acid, respectively). Depending upon the surface functionality $\left(\mathrm{COOH}, \mathrm{NH}_{2}\right.$ or $\mathrm{SH})$, these magnetic nanoadsorbents capture metal ions either by forming chelate complexes, by ion exchange process or else through electrostatic interaction. It has been reported that these surface-engineered $\mathrm{Fe}_{3} \mathrm{O}_{4}$ nanoparticles have a strong affinity for the simultaneous adsorption of 
Table 1 Comparison of different nanomaterials of metal ions and dye removal in view of adsorption capacities and removal rates

\begin{tabular}{|c|c|c|c|c|c|}
\hline Nanomaterials & Adsorbent & Adsorbate & $\begin{array}{l}\text { Adsorption capacity } \\
\left(\mathrm{mg} \mathrm{g}^{-1}\right)\end{array}$ & $\begin{array}{l}\text { Rate constants } \\
\left(k_{1}, \mathrm{~h}^{-1}\right)\end{array}$ & References \\
\hline \multirow[t]{23}{*}{ Carbon-based nanomaterials } & $\mathrm{AC}$ & $\begin{array}{l}\text { Reactive red } \\
\mathrm{M}-2 \mathrm{BE}\end{array}$ & 260.7 & 1.503 & {$[76]$} \\
\hline & PAC & Nitrofurazone & 50.8 & 0.1129 & {$[128]$} \\
\hline & \multirow[t]{4}{*}{ SWCNTs } & $\begin{array}{l}\text { Reactive blue } 29 \\
\text { (RB29) }\end{array}$ & 496 & - & {$[92]$} \\
\hline & & Acid red 18 & 166.67 & 21.12 & [129] \\
\hline & & Reactive red 120 & 426.49 & - & {$[130]$} \\
\hline & & $\mathrm{Cr}(\mathrm{VI})$ & 1.26 & - & [131] \\
\hline & \multirow[t]{6}{*}{ MWCNTs } & $\begin{array}{l}\text { Reactive red } \\
\text { M-2BE }\end{array}$ & 335.7 & 2.860 & {$[76]$} \\
\hline & & Nitrofurazone & 59.9 & 0.2082 & {$[128]$} \\
\hline & & $\mathrm{MB}$ & 95.3 & - & {$[132]$} \\
\hline & & $\mathrm{CR}$ & 352.1 & 3.18 & [133] \\
\hline & & Maxilon blue & 260.7 & - & [134] \\
\hline & & $\mathrm{Cr}(\mathrm{VI})$ & 2.35 & 0.42 & {$[131]$} \\
\hline & Oxidized MWCNTs & $\begin{array}{l}\text { Bromothymol blue } \\
\text { (BTB) }\end{array}$ & 55 & 0.042 & {$[88]$} \\
\hline & \multirow[t]{2}{*}{ Diethylenetriamine-MWCNTs } & $\mathrm{Pb}(\mathrm{II})$ & 58.26 & - & {$[135]$} \\
\hline & & $\mathrm{Cd}(\mathrm{II})$ & 31.45 & - & \\
\hline & GO & $\mathrm{MB}$ & 714 & - & {$[66]$} \\
\hline & \multirow[t]{3}{*}{ rGONSs } & Chlorpyrifos & 1200 & - & [109] \\
\hline & & Endosulfan & 1100 & - & [109] \\
\hline & & Malathion & 800 & - & [109] \\
\hline & \multirow[t]{2}{*}{ Graphene } & $\mathrm{Cd}(\mathrm{II})$ & 106.3 & - & [111] \\
\hline & & $\mathrm{Co}(\mathrm{II})$ & 68.2 & - & \\
\hline & GONSs & $\mathrm{Pb}(\mathrm{II})$ & 842 & - & [114] \\
\hline & GNS & $\mathrm{Ni}(\mathrm{II})$ & 3.00 & 0.0576 & [136] \\
\hline \multirow[t]{12}{*}{ Metal oxide-based nanomaterials } & $\mathrm{Co}_{3} \mathrm{O}_{4} / \mathrm{SiO}_{2}$ nanocomposite & $\mathrm{MB}$ & 53.87 & 1.821 & {$[57]$} \\
\hline & \multirow[t]{3}{*}{$\mathrm{TiO}_{2}$} & $\mathrm{Cd}(\mathrm{II})$ & 16.69 & $2.244^{\mathrm{a}}$ & [67] \\
\hline & & $\mathrm{Cu}(\mathrm{II})$ & 5.18 & $0.927^{\mathrm{a}}$ & \\
\hline & & MO & 85.39 & - & \\
\hline & \multirow[t]{2}{*}{$\mathrm{TiO}_{2}$ nanotubes/CNT } & $\mathrm{Cu}(\mathrm{II})$ & $83-124$ & - & [137] \\
\hline & & $\mathrm{Pb}(\mathrm{II})$ & $192-588$ & - & \\
\hline & $\mathrm{Fe}_{3} \mathrm{O}_{4}$ magnetic nanoparticles & $\mathrm{Cu}(\mathrm{II})$ & 61.07 & - & [124] \\
\hline & $\begin{array}{l}\text { Modifying } \mathrm{Fe}_{3} \mathrm{O}_{4} \\
\text { microspheres }\end{array}$ & $\mathrm{Hg}(\mathrm{II})$ & $37.4\left(\mu \mathrm{mol} \mathrm{g}^{-1}\right)$ & - & [126] \\
\hline & $\begin{array}{l}\text { Ethylenediamine- } \\
\text { functionalized nano- } \mathrm{Fe}_{3} \mathrm{O}_{4}\end{array}$ & $\mathrm{Cr}(\mathrm{VI})$ & 136.98 & $47.172^{\mathrm{a}}$ & {$[51]$} \\
\hline & \multirow[t]{2}{*}{$\mathrm{MgO}$} & Reactive blue 19 & 166.7 & 4.2 & [138] \\
\hline & & Reactive red 198 & 123.5 & 5.4 & \\
\hline & $\delta-\mathrm{MnO}_{2}$ & $\mathrm{Ni}(\mathrm{II})$ & 30.63 & 0.108 & [136] \\
\hline \multirow[t]{7}{*}{$\begin{array}{l}\text { Carbon and metal oxide hybrid } \\
\text { nanomaterials }\end{array}$} & \multirow[t]{2}{*}{$\begin{array}{l}\text { Graphene oxide- }-\mathrm{Fe}_{3} \mathrm{O}_{4} \text { hybrid } \\
\text { composite }\end{array}$} & $\mathrm{MB}$ & 167.2 & - & {$[65]$} \\
\hline & & Neutral Red (NR) & 171.3 & - & \\
\hline & $\mathrm{GNS} / \delta-\mathrm{MnO}_{2}$ composite & $\mathrm{Ni}(\mathrm{II})$ & 46.55 & 0.0432 & [136] \\
\hline & $\mathrm{RGO} / \mathrm{TiO}_{2}$ & $\mathrm{MB}$ & 467.6 & 3.1278 & [139] \\
\hline & \multirow[t]{2}{*}{$\mathrm{Al}_{2} \mathrm{O}_{3} / \mathrm{MWCNTs}$} & Trichloroethylene & 19.84 & $1.1048^{\mathrm{a}}$ & {$[140]$} \\
\hline & & $\mathrm{Cd}(\mathrm{II})$ & 27.21 & $5.7644^{\mathrm{a}}$ & \\
\hline & $\mathrm{MnO}_{2} / \mathrm{CNTs}$ & $\mathrm{Pb}(\mathrm{II})$ & 78.74 & 0.816 & {$[64]$} \\
\hline
\end{tabular}


Table 1 continued

\begin{tabular}{|c|c|c|c|c|c|}
\hline Nanomaterials & Adsorbent & Adsorbate & $\begin{array}{l}\text { Adsorption capacity } \\
\left(\mathrm{mg} \mathrm{g}^{-1}\right)\end{array}$ & $\begin{array}{l}\text { Rate constants } \\
\left(k_{1}, \mathrm{~h}^{-1}\right)\end{array}$ & References \\
\hline & $\begin{array}{c}\mathrm{Ni} @ \mathrm{C} \text { composite } \\
\text { nanostructures }\end{array}$ & $\mathrm{Pb}(\mathrm{II})$ & 21.45 & - & {$[141]$} \\
\hline & & $\mathrm{Cu}(\mathrm{II})$ & 14.3 & - & \\
\hline & & $\mathrm{Cd}(\mathrm{II})$ & 6.43 & - & \\
\hline \multirow[t]{6}{*}{ Polymer-based nanomaterials } & Polyvinyl alcohol & BTB & 276.2 & 4.266 & {$[56]$} \\
\hline & & $\mathrm{MB}$ & 123.3 & 4.854 & \\
\hline & $\begin{array}{l}\text { Polyaniline (PAn)/rice husk } \\
\text { nanocomposite }\end{array}$ & $\mathrm{Zn}(\mathrm{II})$ & 24.3 & - & {$[142]$} \\
\hline & $\begin{array}{l}\text { Polypyrrole } / \mathrm{Fe}_{3} \mathrm{O}_{4} \text { magnetic } \\
\text { nanocomposite }\end{array}$ & $\mathrm{Cr}(\mathrm{VI})$ & 169.4 & 11.28 & {$[143]$} \\
\hline & $\begin{array}{l}\text { Polyacrylamide/ } \mathrm{Ni}_{0.02} \mathrm{Zn}_{0.98} \mathrm{O} \\
\text { nanocomposite }\end{array}$ & $\begin{array}{l}\text { Malachite green } \\
\text { (MG) }\end{array}$ & - & 6.12 & {$[144]$} \\
\hline & & $\begin{array}{l}\text { Rhodamine B } \\
\text { (RB) }\end{array}$ & - & 8.88 & \\
\hline
\end{tabular}

${ }^{\mathrm{a}}\left(k_{2}, \mathrm{~g} \mathrm{mg}^{-1} \mathrm{~h}^{-1}\right)$

$\mathrm{Cr}(\mathrm{III}), \mathrm{Co}(\mathrm{II}), \mathrm{Ni}(\mathrm{II}), \mathrm{Cu}(\mathrm{II}), \mathrm{Cd}(\mathrm{II}), \mathrm{Pb}(\mathrm{II})$ and $\mathrm{As}^{3+}$ from wastewater [45, 47, 48, 51, 68, 118, 123-126]. In addition, the adsorption process was found to be highly dependent on the amount, surface functionality and $\mathrm{pH}$ of the medium, which caused these nanoparticles to selectively adsorb metal ions [125-127]. An almost 100\% removal rate of $\mathrm{Cr}(\mathrm{III}), \mathrm{Co}(\mathrm{II}), \mathrm{Ni}(\mathrm{II}), \mathrm{Cu}(\mathrm{II}), \mathrm{Cd}(\mathrm{II})$ and $\mathrm{Pb}(\mathrm{II})$ ions from water was reported at $\mathrm{pH}>8$ by these functionalized nanoparticles [124-127].

The removal efficiency of As(III) by carboxyl, amine and thiol-functionalized $\mathrm{Fe}_{3} \mathrm{O}_{4}$ was found to be 91, 95 and $97 \%$, respectively, at $\mathrm{pH} 8$ [43]. The adsorption-desorption behavior of metal ions on amine-functionalized $\mathrm{Fe}_{3} \mathrm{O}_{4}$ showed an $85 \%$ desorption ratio in the first cycle, which indicates their excellent regeneration capacity for their further use. It was reported that ethylenediaminetetraacetic acid-functionalized (EDTA) $\mathrm{Fe}_{3} \mathrm{O}_{4}$ nanomagnetic chelators (NMCs), show a strong tendency towards the adsorption of $\mathrm{Cr}$ (III), $\mathrm{Co}$ (II), $\mathrm{Ni}(\mathrm{II}), \mathrm{Cu}(\mathrm{II}), \mathrm{Cd}(\mathrm{II})$ and $\mathrm{Pb}$ (II) from wastewater [67].

Ozmen et al. [124] reported the use of 3-aminopropyltriethoxysilane and glutaraldehyde-modified $\mathrm{Fe}_{3} \mathrm{O}_{4}$ nanoparticles for the removal of $\mathrm{Cu}(\mathrm{II})$ from the water. Ge et al. [125] have studied the effective removal of heavy metal ions [Cd(II), $\mathrm{Zn}(\mathrm{II}), \mathrm{Pb}(\mathrm{II})$ and $\mathrm{Cu}(\mathrm{II})]$ from an aqueous solution using a polymer-modified magnetic nanoparticles. They reported a higher removal efficiency of metal ions in acidic pH 5.5 and a lower one in alkaline $\mathrm{pH}$. Based on their results, they have suggested that the polymer-modified $\mathrm{Fe}_{3} \mathrm{O}_{4}$ was more efficient than bare $\mathrm{Fe}_{3} \mathrm{O}_{4}$. The reported studies suggest that the functional groups present on the surface of magnetic nanoparticles provide a large number of active sites as well as aqueous stability, which is necessary for the successful adsorption of toxic metals from water. More specifically, these surface-engineered magnetic nanoparticles are highly effective, efficient, economically viable, and reusable magnetic nanoadsorbents for the removal of toxic metal ions from water.

Magnetic nanoparticles were also successfully used as adsorbents of toxic metal ions from different sources. Rhodamine hydrazide modifying $\mathrm{Fe}_{3} \mathrm{O}_{4}$ microspheres $\left(\mathrm{Fe}_{3} \mathrm{O}_{4}-\mathrm{R} 6 \mathrm{G}\right)$ has been reported for the selective detection and removal of mercury ions from different environmental samples, such as tap water, lake water and river water [126]. It was found that, $1.5 \times 10^{-7} \mathrm{~mol} \mathrm{~L}^{-1}$ is the detection limit for $\mathrm{Hg}(\mathrm{II})$ and that $37.4 \mu \mathrm{mol} \mathrm{g}^{-1}$ is the maximum adsorption of $\mathrm{Hg}$ (II) in $3 \mathrm{~mL}$ sample with $5 \mathrm{mg}$ $\mathrm{Fe}_{3} \mathrm{O}_{4}$-R6G. In addition, the regeneration capability for up to three cycles was studied, and observed that it could reversibly bind with $\mathrm{Hg}$ ions repeatedly. Table 1 compares the adsorption capacities and removal rates for some dyes and metal ions on different kinds of nanomaterials. A comparison between the removal of different dyes using MWCNTs and the removal of methylene blue, $\mathrm{Cd}(\mathrm{II})$ and $\mathrm{Pd}(\mathrm{II})$ by different nanomaterials is displayed in Fig. 5.

\section{Conclusions}

The presence of heavy metal ions and dyes in wastewater is a major concern for environment conservation and human health. The removal process of these ions has not reached the optimum conditions. Based on the unique properties of nanomaterials, they have been widely studied for heavy metals and dye removals from wastewater due to their high surface area, low particles size which leads to high numbers of adsorption active centers. Adsorption processes 

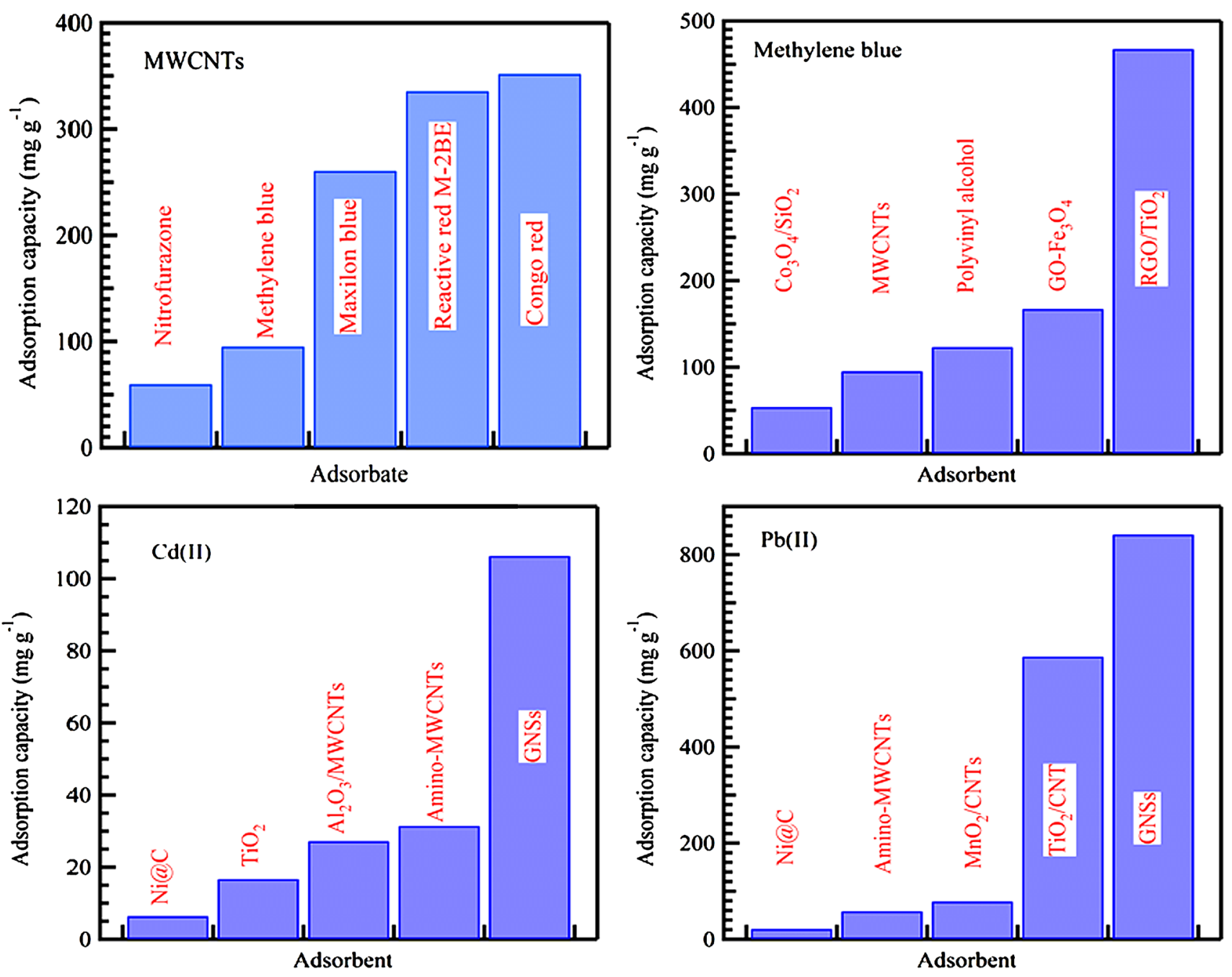

Fig. 5 A comparison of removal of different dyes by MWCNTs; and removal of methylene blue, Cd(II) and Pd(II) by different nanomaterials

using nanomaterials are highly effective, may be easily performed and employed for the removal of organic and inorganic pollutants. It seems very plausible that these types of adsorbents may find wide commercial application in wastewater treatment in the near future.

This article reviews the past, present and future approaches for using nanomaterials as effective adsorbents for the removal of heavy metal ions and dyes from wastewater. The recent trends of using nanomaterials as cost-effective and environmentally acceptable adsorbents for water purification were discussed in this article. This review highlights the promising future applications of nanomaterials as adsorbents because of their unique morphological and structural properties.

Open Access This article is distributed under the terms of the Creative Commons Attribution 4.0 International License (http://crea tivecommons.org/licenses/by/4.0/), which permits unrestricted use, distribution, and reproduction in any medium, provided you give appropriate credit to the original author(s) and the source, provide a link to the Creative Commons license, and indicate if changes were made.

\section{References}

1. Becher, G.: Drinking water chlorination and health. Acta Hydrochim. Hydrobiol. 27(2), 100-102 (1999)

2. Zwiener, C., Richardson, S.D., De Marini, D.M., Grummt, T., Glauner, T., Frimmel, F.H.: Drowning in disinfection byproducts? Assessing swimming pool water. Environ. Sci. Technol. 41(2), 363-372 (2007)

3. Karnik, B., Davies, S., Baumann, M., Masten, S.: The effects of combined ozonation and filtration on disinfection by-product formation. Water Res. 39(13), 2839-2850 (2005)

4. Zhang, X., Minear, R.A., Guo, Y., Hwang, C.J., Barrett, S.E., Ikeda, K., Shimizu, Y., Matsui, S.: An electrospray ionizationtandem mass spectrometry method for identifying chlorinated drinking water disinfection byproducts. Water Res. 38(18), 3920-3930 (2004)

5. Carballa, M., Omil, F., Lema, J.M., Llompart, M.A., GarcíaJares, C., Rodríguez, I., Gomez, M., Ternes, T.: Behavior of 
pharmaceuticals, cosmetics and hormones in a sewage treatment plant. Water Res. 38(12), 2918-2926 (2004)

6. Joss, A., Zabczynski, S., Göbel, A., Hoffmann, B., Löffler, D., McArdell, C.S., Ternes, T.A., Thomsen, A., Siegrist, H.: Biological degradation of pharmaceuticals in municipal wastewater treatment: proposing a classification scheme. Water Res. 40(8), 1686-1696 (2006)

7. Lissemore, L., Hao, C., Yang, P., Sibley, P.K., Mabury, S., Solomon, K.R.: An exposure assessment for selected pharmaceuticals within a watershed in Southern Ontario. Chemosphere 64(5), 717-729 (2006)

8. Andersen, H., Siegrist, H., Halling-Sørensen, B., Ternes, T.A.: Fate of estrogens in a municipal sewage treatment plant. Environ. Sci. Technol. 37(18), 4021-4026 (2003)

9. Miao, X.-S., Bishay, F., Chen, M., Metcalfe, C.D.: Occurrence of antimicrobials in the final effluents of wastewater treatment plants in Canada. Environ. Sci. Technol. 38(13), 3533-3541 (2004)

10. Saha, N., Rahman, M.S., Ahmed, M.B., Zhou, J.L., Ngo, H.H., Guo, W.: Industrial metal pollution in water and probabilistic assessment of human health risk. J. Environ. Manag. 185, 70-78 (2017)

11. Halling-Sørensen, B., Nielsen, S.N., Lanzky, P., Ingerslev, F., Lützhøft, H.H., Jørgensen, S.: Occurrence, fate and effects of pharmaceutical substances in the environment-a review. Chemosphere 36(2), 357-393 (1998)

12. Glassmeyer, S.T., Furlong, E.T., Kolpin, D.W., Cahill, J.D., Zaugg, S.D., Werner, S.L., Meyer, M.T., Kryak, D.D.: Transport of chemical and microbial compounds from known wastewater discharges: potential for use as indicators of human fecal contamination. Environ. Sci. Technol. 39(14), 5157-5169 (2005)

13. Molinari, R., Poerio, T., Cassano, R., Picci, N., Argurio, P.: Copper (II) removal from wastewaters by a new synthesized selective extractant and SLM viability. Ind. Eng. Chem. Fundam. 43(2), 623-628 (2004)

14. Al-Degs, Y.S., El-Barghouthi, M.I., Issa, A.A., Khraisheh, M.A., Walker, G.M.: Sorption of $\mathrm{Zn}$ (II), Pb(II), and Co (II) using natural sorbents: equilibrium and kinetic studies. Water Res. 40(14), 2645-2658 (2006)

15. Sadegh, H., Shahryari-ghoshekandi, R., Agarwal, S., Tyagi, I., Asif, M., Gupta, V.K.: Microwave-assisted removal of malachite green by carboxylate functionalized multi-walled carbon nanotubes: kinetics and equilibrium study. J. Mol. Liq. 206, 151-158 (2015)

16. Babel, S., Kurniawan, T.A.: Low-cost adsorbents for heavy metals uptake from contaminated water: a review. J. Hazard. Mater. 97(1), 219-243 (2003)

17. Karimi, L., Zohoori, S.: Superior photocatalytic degradation of azo dyes in aqueous solutions using $\mathrm{TiO}_{2} / \mathrm{SrTiO}_{3}$ nanocomposite. J. Nanostruct. Chem. 3(1), 32 (2013)

18. Islam, M.S., Choi, W.S., Nam, B., Yoon, C., Lee, H.-J.: Needlelike iron oxide@ $\mathrm{CaCO}_{3}$ adsorbents for ultrafast removal of anionic and cationic heavy metal ions. Chem. Eng. J. 307, 208-219 (2017)

19. Bansal, R.C., Goyal, M.: Activated Carbon Adsorption. CRC Press, Boca Raton (2005)

20. Khlifi, R., Hamza-Chaffai, A.: Head and neck cancer due to heavy metal exposure via tobacco smoking and professional exposure: a review. Toxicol. Appl. Pharmacol. 248(2), 71-88 (2010)

21. Ernhart, C.B.: A critical review of low-level prenatal lead exposure in the human: 1. Effects on the fetus and newborn. Reprod. Toxicol. 6(1), 9-19 (1992)

22. Zare, K., Gupta, V.K., Moradi, O., Makhlouf, A.S.H., Sillanpää, M., Nadagouda, M.N., Sadegh, H., Shahryari-ghoshekandi, R., Pal, A., Wang, Z.-J.: A comparative study on the basis of adsorption capacity between CNTs and activated carbon as adsorbents for removal of noxious synthetic dyes: a review. J. Nanostruct. Chem. 5(2), 227-236 (2015)

23. Sadegh, H., Shahryari-Ghoshekandi, R., Tyagi, I., Agarwal, S., Gupta, V.K.: Kinetic and thermodynamic studies for alizarin removal from liquid phase using poly-2-hydroxyethyl methacrylate (PHEMA). J. Mol. Liq. 207, 21-27 (2015)

24. Rao, M.M., Ramesh, A., Rao, G.P.C., Seshaiah, K.: Removal of copper and cadmium from the aqueous solutions by activated carbon derived from Ceiba pentandra hulls. J. Hazard. Mater. 129(1), 123-129 (2006)

25. Biškup, B., Subotić, B.: Removal of heavy metal ions from solutions using zeolites. III. Influence of sodium ion concentration in the liquid phase on the kinetics of exchange processes between cadmium ions from solution and sodium ions from zeolite A. Sep. Sci. Technol. 39(4), 925-940 (2005)

26. Gupta, V., Moradi, O., Tyagi, I., Agarwal, S., Sadegh, H., Shahryari-Ghoshekandi, R., Makhlouf, A., Goodarzi, M., Garshasbi, A.: Study on the removal of heavy metal ions from industry waste by carbon nanotubes: effect of the surface modification: a review. Crit. Rev. Environ. Sci. Technol. 46(2), 93-118 (2016)

27. Ekmekyapar, F., Aslan, A., Bayhan, Y.K., Cakici, A.: Biosorption of copper (II) by nonliving lichen biomass of Cladonia rangiformis hoffm. J. Hazard. Mater. 137(1), 293-298 (2006)

28. Arias, M., Barral, M., Mejuto, J.: Enhancement of copper and cadmium adsorption on kaolin by the presence of humic acids. Chemosphere 48(10), 1081-1088 (2002)

29. Gupta, V.K., Tyagi, I., Agarwal, S., Sadegh, H., Shahryarighoshekandi, R., Yari, M., Yousefi-nejat, O.: Experimental study of surfaces of hydrogel polymers HEMA, HEMAEEMA-MA, and PVA as adsorbent for removal of azo dyes from liquid phase. J. Mol. Liq. 206, 129-136 (2015)

30. Chu, W.: Lead metal removal by recycled alum sludge. Water Res. 33(13), 3019-3025 (1999)

31. Sublet, R., Simonnot, M.-O., Boireau, A., Sardin, M.: Selection of an adsorbent for lead removal from drinking water by a point-of-use treatment device. Water Res. 37(20), 4904-4912 (2003)

32. Rickerby, D., Morrison, M.: Nanotechnology and the environment: a European perspective. Sci. Technol. Adv. Mater. 8(1), 19-24 (2007)

33. Brumfiel, G.: Nanotechnology: a little knowledge. Nature 424(6946), 246-248 (2003)

34. Sadegh, H., Ghoshekandi, R.S., Masjedi, A., Mahmoodi, Z., Kazemi, M.: A review on Carbon nanotubes adsorbents for the removal of pollutants from aqueous solutions. Int. J. Nano Dimens. 7(2), 109 (2016)

35. Theron, J., Walker, J., Cloete, T.: Nanotechnology and water treatment: applications and emerging opportunities. Crit. Rev. Microbiol. 34(1), 43-69 (2008)

36. Dil, E.A., Ghaedi, M., Asfaram, A.: The performance of nanorods material as adsorbent for removal of azo dyes and heavy metal ions: application of ultrasound wave, optimization and modeling. Ultrason. Sonochem. 34, 792-802 (2017)

37. Savage, N., Diallo, M.S.: Nanomaterials and water purification: opportunities and challenges. J. Nanopart. Res. 7(4-5), 331-342 (2005)

38. Machida, M., Mochimaru, T., Tatsumoto, H.: Lead (II) adsorption onto the graphene layer of carbonaceous materials in aqueous solution. Carbon 44(13), 2681-2688 (2006)

39. Sharma, Y., Srivastava, V., Singh, V., Kaul, S., Weng, C.: Nanoadsorbents for the removal of metallic pollutants from water and wastewater. Environ. Technol. 30(6), 583-609 (2009)

40. Ali, I.: New generation adsorbents for water treatment. Chem. Rev. 112(10), 5073-5091 (2012) 
41. Chen, C., Wang, X.: Adsorption of Ni (II) from aqueous solution using oxidized multiwall carbon nanotubes. Ind. Eng. Chem. Fundam. 45(26), 9144-9149 (2006)

42. Wang, S., Sun, H., Ang, H.-M., Tadé, M.: Adsorptive remediation of environmental pollutants using novel graphene-based nanomaterials. Chem. Eng. J. 226, 336-347 (2013)

43. Luo, T., Cui, J., Hu, S., Huang, Y., Jing, C.: Arsenic removal and recovery from copper smelting wastewater using $\mathrm{TiO}_{2}$. Environ. Sci. Technol. 44(23), 9094-9098 (2010)

44. Singh, S., Barick, K., Bahadur, D.: Functional oxide nanomaterials and nanocomposites for the removal of heavy metals and dyes. Nanomater. Nanotechnol. 3, 3-20 (2013)

45. Feng, J., Zhang, D.-D., Liu, Y.-F., Bai, Y., Chen, Q.-D., Liu, S.Y., Sun, H.-B.: Magnetic nanofilm of $\mathrm{Fe}_{3} \mathrm{O}_{4}$ for highly efficient organic light-emitting devices. J. Phys. Chem. C 114(14), 6718-6721 (2010)

46. Singh, S., Barick, K., Bahadur, D.: Novel and efficient three dimensional mesoporous $\mathrm{ZnO}$ nanoassemblies for environmental remediation. Int. J. Nanosci. 10(4-5), 1001-1005 (2011)

47. Shen, Y., Tang, J., Nie, Z., Wang, Y., Ren, Y., Zuo, L.: Preparation and application of magnetic $\mathrm{Fe}_{3} \mathrm{O}_{4}$ nanoparticles for wastewater purification. Sep. Purif. Technol. 68(3), 312-319 (2009)

48. Wang, L., Li, J., Jiang, Q., Zhao, L.: Water-soluble $\mathrm{Fe}_{3} \mathrm{O}_{4}$ nanoparticles with high solubility for removal of heavy-metal ions from waste water. Dalton Trans. 41(15), 4544-4551 (2012)

49. Tuzen, M., Soylak, M.: Multiwalled carbon nanotubes for speciation of chromium in environmental samples. J. Hazard. Mater. 147(1), 219-225 (2007)

50. Moradi, O., Sadegh, H., Shahryari-Ghoshekandi, R., Norouzi, M.: Application of Carbon Nanotubes in Nanomedicine: New Medical Approach for Tomorrow, pp. 90-128. Handbook of Research on Diverse Applications of Nanotechnology in Biomedicine, Chemistry, and Engineering, Hershey (2015)

51. Zhao, Y.-G., Shen, H.-Y., Pan, S.-D., Hu, M.-Q., Xia, Q.-H.: Preparation and characterization of amino-functionalized nano$\mathrm{Fe}_{3} \mathrm{O}_{4}$ magnetic polymer adsorbents for removal of chromium (VI) ions. J. Mater. Sci. 45(19), 5291-5301 (2010)

52. Apul, O.G., Wang, Q., Zhou, Y., Karanfil, T.: Adsorption of aromatic organic contaminants by graphene nanosheets: comparison with carbon nanotubes and activated carbon. Water Res. 47(4), 1648-1654 (2013)

53. Sadegh, H., Zare, K., Maazinejad, B., Shahryari-Ghoshekandi, R., Tyagi, I., Agarwal, S., Gupta, V.K.: Synthesis of MWCNTCOOH-Cysteamine composite and its application for dye removal. J. Mol. Liq. 215, 221-228 (2016)

54. Kurniawan, T.A., Lo, W.-H.: Removal of refractory compounds from stabilized landfill leachate using an integrated $\mathrm{H}_{2} \mathrm{O}_{2}$ oxidation and granular activated carbon (GAC) adsorption treatment. Water Res. 43(16), 4079-4091 (2009)

55. Ho, Y.-S., McKay, G.: Sorption of dye from aqueous solution by peat. Chem. Eng. J. 70(2), 115-124 (1998)

56. Agarwal, S., Sadegh, H., Monajjemi, M., Hamdy, A.S., Ali, G.A.M., Memar, A.O., Shahryari-ghoshekandi, R., Tyagi, I., Gupta, V.K.: Efficient removal of toxic bromothymol blue and methylene blue from wastewater by polyvinyl alcohol. J. Mol. Liq. 218, 191-197 (2016)

57. Abdel Ghafar, H.H., Ali, G.A.M., Fouad, O.A., Makhlouf, S.A.: Enhancement of adsorption efficiency of methylene blue on $\mathrm{Co}_{3} \mathrm{O}_{4} / \mathrm{SiO}_{2}$ nanocomposite. Desalin. Water Treat. 53(11), 2980-2989 (2015)

58. Faust, S.D., Aly, O.M.: Adsorption Processes for Water Treatment. Elsevier, Amsterdam (2013)

59. Yuh-Shan, H.: Citation review of Lagergren kinetic rate equation on adsorption reactions. Scientometrics 59(1), 171-177 (2004)
60. Ho, Y.-S.: Review of second-order models for adsorption systems. J. Hazard. Mater. 136(3), 681-689 (2006)

61. Graydon, J.W., Zhang, X., Kirk, D.W., Jia, C.Q.: Sorption and stability of mercury on activated carbon for emission control. J. Hazard. Mater. 168(2), 978-982 (2009)

62. Gupta, K., Bhattacharya, S., Chattopadhyay, D., Mukhopadhyay, A., Biswas, H., Dutta, J., Ray, N.R., Ghosh, U.C.: Ceria associated manganese oxide nanoparticles: synthesis, characterization and arsenic (V) sorption behavior. Chem. Eng. J. 172(1), 219-229 (2011)

63. Ji, L., Chen, W., Xu, Z., Zheng, S., Zhu, D.: Graphene nanosheets and graphite oxide as promising adsorbents for removal of organic contaminants from aqueous solution. J. Environ. Qual. 42(1), 191-198 (2013)

64. Wang, S.-G., Gong, W.-X., Liu, X.-W., Yao, Y.-W., Gao, B.-Y., Yue, Q.-Y.: Removal of lead(II) from aqueous solution by adsorption onto manganese oxide-coated carbon nanotubes. Sep. Purif. Technol. 58(1), 17-23 (2007)

65. Xie, G., Xi, P., Liu, H., Chen, F., Huang, L., Shi, Y., Hou, F., Zeng, Z., Shao, C., Wang, J.: A facile chemical method to produce superparamagnetic graphene oxide- $\mathrm{Fe}_{3} \mathrm{O}_{4}$ hybrid composite and its application in the removal of dyes from aqueous solution. J. Mater. Chem. 22(3), 1033-1039 (2012)

66. Yang, S.-T., Chen, S., Chang, Y., Cao, A., Liu, Y., Wang, H.: Removal of methylene blue from aqueous solution by graphene oxide. J. Colloid Interface Sci. 359(1), 24-29 (2011)

67. Visa, M., Carcel, R.A., Andronic, L., Duta, A.: Advanced treatment of wastewater with methyl orange and heavy metals on $\mathrm{TiO}_{2}$, fly ash and their mixtures. Catal. Today 144(1), 137-142 (2009)

68. Singh, S., Barick, K., Bahadur, D.: $\mathrm{Fe}_{3} \mathrm{O}_{4}$ embedded $\mathrm{ZnO}$ nanocomposites for the removal of toxic metal ions, organic dyes and bacterial pathogens. J. Mater. Chem. A 1(10), 3325-3333 (2013)

69. Ghaedi, M., Shokrollahi, A., Tavallali, H., Shojaiepoor, F., Keshavarz, B., Hossainian, H., Soylak, M., Purkait, M.: Activated carbon and multiwalled carbon nanotubes as efficient adsorbents for removal of arsenazo (III) and methyl red from waste water. Toxicol. Environ. Chem. 93(3), 438-449 (2011)

70. Chen, C., Li, X., Zhao, D., Tan, X., Wang, X.: Adsorption kinetic, thermodynamic and desorption studies of Th(IV) on oxidized multi-wall carbon nanotubes. Colloids Surf. A 302(1), 449-454 (2007)

71. Li, Y.-H., Ding, J., Luan, Z., Di, Z., Zhu, Y., Xu, C., Wu, D., Wei, B.: Competitive adsorption of $\mathrm{Pb}^{2+}, \mathrm{Cu}^{2+}$ and $\mathrm{Cd}^{2+}$ ions from aqueous solutions by multiwalled carbon nanotubes. Carbon 41(14), 2787-2792 (2003)

72. Chatterjee, S., Lee, M.W., Woo, S.H.: Adsorption of congo red by chitosan hydrogel beads impregnated with carbon nanotubes. Bioresour. Technol. 101(6), 1800-1806 (2010)

73. Chatterjee, S., Chatterjee, T., Lim, S.-R., Woo, S.H.: Effect of the addition mode of carbon nanotubes for the production of chitosan hydrogel core-shell beads on adsorption of Congo red from aqueous solution. Bioresour. Technol. 102(6), 4402-4409 (2011)

74. Bina, B., Amin, M., Rashidi, A., Pourzamani, H.: Benzene and toluene removal by carbon nanotubes from aqueous solution. Arch. Environ. Prot. 38(1), 3-25 (2012)

75. Rodríguez, A., Ovejero, G., Sotelo, J.L., Mestanza, M., García, J.: Adsorption of dyes on carbon nanomaterials from aqueous solutions. J. Environ. Sci. Health Part A 45(12), 1642-1653 (2010)

76. Machado, F.M., Bergmann, C.P., Fernandes, T.H.M., Lima, E.C., Royer, B., Calvete, T., Fagan, S.B.: Adsorption of Reactive Red M-2BE dye from water solutions by multi-walled carbon nanotubes and activated carbon. J. Hazard. Mater. 192(3), 1122-1131 (2011) 
77. Iijima, S.: Helical microtubules of graphitic carbon. Nature 354(6348), 56-58 (1991)

78. Li, Y.-H., Wang, S., Luan, Z., Ding, J., Xu, C., Wu, D.: Adsorption of cadmium (II) from aqueous solution by surface oxidized carbon nanotubes. Carbon 41(5), 1057-1062 (2003)

79. Stafiej, A., Pyrzynska, K.: Adsorption of heavy metal ions with carbon nanotubes. Sep. Purif. Technol. 58(1), 49-52 (2007)

80. Pyrzyńska, K., Bystrzejewski, M.: Comparative study of heavy metal ions sorption onto activated carbon, carbon nanotubes, and carbon-encapsulated magnetic nanoparticles. Colloids Surf. A 362(1), 102-109 (2010)

81. Xu, D., Tan, X., Chen, C., Wang, X.: Removal of $\mathrm{Pb}$ (II) from aqueous solution by oxidized multiwalled carbon nanotubes. J. Hazard. Mater. 154(1), 407-416 (2008)

82. Chen, C., Hu, J., Xu, D., Tan, X., Meng, Y., Wang, X.: Surface complexation modeling of $\mathrm{Sr}$ (II) and $\mathrm{Eu}(\mathrm{III})$ adsorption onto oxidized multiwall carbon nanotubes. J. Colloid Interface Sci. 323(1), 33-41 (2008)

83. Ghaedi, M., Haghdoust, S., Kokhdan, S.N., Mihandoost, A., Sahraie, R., Daneshfar, A.: Comparison of activated carbon, multiwalled carbon nanotubes, and cadmium hydroxide nanowire loaded on activated carbon as adsorbents for kinetic and equilibrium study of removal of Safranine O. Spectrosc. Lett. 45(7), 500-510 (2012)

84. Bahgat, M., Farghali, A., El Rouby, W., Khedr, M.: Synthesis and modification of multi-walled carbon nano-tubes (MWCNTs) for water treatment applications. J. Anal. Appl. Pyrolysis 92(2), 307-313 (2011)

85. Ghaedi, M., Shokrollahi, A., Hossainian, H., Kokhdan, S.N.: Comparison of activated carbon and multiwalled carbon nanotubes for efficient removal of eriochrome cyanine R (ECR): kinetic, isotherm, and thermodynamic study of the removal process. J. Chem. Eng. Data 56(7), 3227-3235 (2011)

86. Chang, Z.-D., Zhang, J.-H., Liu, Y.: Removal of methyl orange from aqueous solution by magnetic carbon nanotubes. Spectrosc. Spectr. Anal. 31(1), 205-209 (2011)

87. Ghaedi, M., Kokhdan, S.N.: Oxidized multiwalled carbon nanotubes for the removal of methyl red (MR): kinetics and equilibrium study. Desalination Water Treat. 49(1-3), 317-325 (2012)

88. Ghaedi, M., Khajehsharifi, H., Yadkuri, A.H., Roosta, M., Asghari, A.: Oxidized multiwalled carbon nanotubes as efficient adsorbent for bromothymol blue. Toxicol. Environ. Chem. 94(5), 873-883 (2012)

89. Yao, Y., Xu, F., Chen, M., Xu, Z., Zhu, Z.: Adsorption of cationic methyl violet and methylene blue dyes onto carbon nanotubes. In: Nano/Micro Engineered and Molecular Systems (NEMS), 2010 5th IEEE International Conference on (2010)

90. Shahryari, Z., Goharrizi, A.S., Azadi, M.: Experimental study of methylene blue adsorption from aqueous solutions onto carbon nano tubes. Int. J. Water Res. Environ. Eng. 2(2), 16-28 (2010)

91. Salama, A.: New sustainable hybrid material as adsorbent for dye removal from aqueous solutions. J. Colloid Interface Sci. 487, 348-353 (2017)

92. Nadafi, K., Mesdaghinia, A., Nabizadeh, R., Younesian, M., Rad, M.J.: The combination and optimization study on RB29 dye removal from water by peroxy acid and single-wall carbon nanotubes. Desalination Water Treat. 27(1-3), 237-242 (2011)

93. Li, Y.-H., Wang, S., Wei, J., Zhang, X., Xu, C., Luan, Z., Wu, D., Wei, B.: Lead adsorption on carbon nanotubes. Chem. Phys. Lett. 357(3), 263-266 (2002)

94. Robati, D.: Pseudo-second-order kinetic equations for modeling adsorption systems for removal of lead ions using multi-walled carbon nanotube. J. Nanostruct. Chem. 3(1), 55 (2013)
95. Gao, Z., Bandosz, T.J., Zhao, Z., Han, M., Qiu, J.: Investigation of factors affecting adsorption of transition metals on oxidized carbon nanotubes. J. Hazard. Mater. 167(1), 357-365 (2009)

96. Wang, X., Chen, C., Hu, W., Ding, A., Xu, D., Zhou, X.: Sorption of $243 \mathrm{Am}$ (III) to multiwall carbon nanotubes. Environ. Sci. Technol. 39(8), 2856-2860 (2005)

97. Tan, X., Xu, D., Chen, C., Wang, X., Hu, W.: Adsorption and kinetic desorption study of $152+154 \mathrm{Eu}$ (III) on multiwall carbon nanotubes from aqueous solution by using chelating resin and XPS methods. Radiochim. Acta 96(1/2008), 23-29 (2008)

98. Rao, G.P., Lu, C., Su, F.: Sorption of divalent metal ions from aqueous solution by carbon nanotubes: a review. Sep. Purif. Technol. 58(1), 224-231 (2007)

99. Moradi, O., Gupta, V.K., Agarwal, S., Tyagi, I., Asif, M., Makhlouf, A.S.H., Sadegh, H., Shahryari-ghoshekandi, R.: Characteristics and electrical conductivity of graphene and graphene oxide for adsorption of cationic dyes from liquids: kinetic and thermodynamic study. J. Ind. Eng. Chem. 28, 294-301 (2015)

100. Shahryari-ghoshekandi, R., Sadegh, H.: Kinetic study of the adsorption of synthetic dyes on graphene surfaces. Jordan J. Chem. 9(4), 267-278 (2014)

101. Denis, P.A., Iribarne, F.: A first-principles study on the interaction between alkyl radicals and graphene. Chem. Eur. J. 18(24), 7568-7574 (2012)

102. Yu, J.-G., Zhao, X.-H., Yang, H., Chen, X.-H., Yang, Q., Yu, L.Y., Jiang, J.-H., Chen, X.-Q.: Aqueous adsorption and removal of organic contaminants by carbon nanotubes. Sci. Total Environ. 482, 241-251 (2014)

103. Kotov, N.A.: Materials science: carbon sheet solutions. Nature 442(7100), 254-255 (2006)

104. Li, Y., Liu, T., Du, Q., Sun, J., Xia, Y., Wang, Z., Zhang, W., Wang, K., Zhu, H., Wu, D.: Adsorption of cationic red X-GRL from aqueous solutions by graphene: equilibrium, kinetics and thermodynamics study. Chem. Biochem. Eng. Q 25(4), 483-491 (2012)

105. Li, B., Cao, H., Yin, G.: $\mathrm{Mg}(\mathrm{OH})_{2} @$ reduced graphene oxide composite for removal of dyes from water. J. Mater. Chem. 21(36), 13765-13768 (2011)

106. Li, N., Zheng, M., Chang, X., Ji, G., Lu, H., Xue, L., Pan, L., Cao, J.: Preparation of magnetic $\mathrm{CoFe}_{2} \mathrm{O}_{4}$-functionalized graphene sheets via a facile hydrothermal method and their adsorption properties. J. Solid State Chem. 184(4), 953-958 (2011)

107. Du, Q., Sun, J., Li, Y., Yang, X., Wang, X., Wang, Z., Xia, L.: Highly enhanced adsorption of congo red onto graphene oxide/chitosan fibers by wet-chemical etching off silica nanoparticles. Chem. Eng. J. 245, 99-106 (2014)

108. Wu, T., Cai, X., Tan, S., Li, H., Liu, J., Yang, W.: Adsorption characteristics of acrylonitrile, p-toluenesulfonic acid, 1-naphthalenesulfonic acid and methyl blue on graphene in aqueous solutions. Chem. Eng. J. 173(1), 144-149 (2011)

109. Maliyekkal, S.M., Sreeprasad, T.S., Krishnan, D., Kouser, S., Mishra, A.K., Waghmare, U.V., Pradeep, T.: Graphene: a reusable substrate for unprecedented adsorption of pesticides. Small 9(2), 273-283 (2013)

110. Yu, J.-G., Yu, L.-Y., Yang, H., Liu, Q., Chen, X.-H., Jiang, X.Y., Chen, X.-Q., Jiao, F.-P.: Graphene nanosheets as novel adsorbents in adsorption, preconcentration and removal of gases, organic compounds and metal ions. Sci. Total Environ. 502, 70-79 (2015)

111. Zhao, G., Li, J., Ren, X., Chen, C., Wang, X.: Few-layered graphene oxide nanosheets as superior sorbents for heavy metal ion pollution management. Environ. Sci. Technol. 45(24), 10454-10462 (2011) 
112. Chandra, V., Park, J., Chun, Y., Lee, J.W., Hwang, I.-C., Kim, K.S.: Water-dispersible magnetite-reduced graphene oxide composites for arsenic removal. ACS Nano 4(7), 3979-3986 (2010)

113. Yang, S.-T., Chang, Y., Wang, H., Liu, G., Chen, S., Wang, Y., Liu, Y., Cao, A.: Folding/aggregation of graphene oxide and its application in $\mathrm{Cu}^{2+}$ removal. J. Colloid Interface Sci. 351(1), 122-127 (2010)

114. Zhao, G., Ren, X., Gao, X., Tan, X., Li, J., Chen, C., Huang, Y., Wang, X.: Removal of $\mathrm{Pb}(\mathrm{II})$ ions from aqueous solutions on few-layered graphene oxide nanosheets. Dalton Trans. 40(41), 10945-10952 (2011)

115. Zhao, G., Wen, T., Yang, X., Yang, S., Liao, J., Hu, J., Shao, D., Wang, X.: Preconcentration of U (VI) ions on few-layered graphene oxide nanosheets from aqueous solutions. Dalton Trans. 41(20), 6182-6188 (2012)

116. Gao, W., Majumder, M., Alemany, L.B., Narayanan, T.N., Ibarra, M.A., Pradhan, B.K., Ajayan, P.M.: Engineered graphite oxide materials for application in water purification. ACS Appl. Mater. Interfaces 3(6), 1821-1826 (2011)

117. Madadrang, C.J., Kim, H.Y., Gao, G., Wang, N., Zhu, J., Feng, H., Gorring, M., Kasner, M.L., Hou, S.: Adsorption behavior of EDTA-graphene oxide for $\mathrm{Pb}(\mathrm{II})$ removal. ACS Appl. Mater. Interfaces 4(3), 1186-1193 (2012)

118. Feng, L., Cao, M., Ma, X., Zhu, Y., Hu, C.: Superparamagnetic high-surface-area $\mathrm{Fe}_{3} \mathrm{O}_{4}$ nanoparticles as adsorbents for arsenic removal. J. Hazard. Mater. 217, 439-446 (2012)

119. Gao, C., Zhang, W., Li, H., Lang, L., Xu, Z.: Controllable fabrication of mesoporous $\mathrm{MgO}$ with various morphologies and their absorption performance for toxic pollutants in water. Cryst. Growth Des. 8(10), 3785-3790 (2008)

120. Tadjarodi, A., Imani, M., Kerdari, H.: Adsorption kinetics, thermodynamic studies, and high performance of $\mathrm{CdO}$ cauliflower-like nanostructure on the removal of Congo red from aqueous solution. J. Nanostruct. Chem. 3(1), 51 (2013)

121. Cao, C.-Y., Cui, Z.-M., Chen, C.-Q., Song, W.-G., Cai, W.: Ceria hollow nanospheres produced by a template-free microwave-assisted hydrothermal method for heavy metal ion removal and catalysis. J. Phys. Chem. C 114(21), 9865-9870 (2010)

122. Deliyanni, E.A., Lazaridis, N.K., Peleka, E.N., Matis, K.A.: Metals removal from aqueous solution by iron-based bonding agents. Environ. Sci. Pollut. Res. 11(1), 18-21 (2004)

123. Zare, K., Sadegh, H., Shahryari-ghoshekandi, R., Asif, M., Tyagi, I., Agarwal, S., Gupta, V.K.: Equilibrium and kinetic study of ammonium ion adsorption by $\mathrm{Fe}_{3} \mathrm{O}_{4}$ nanoparticles from aqueous solutions. J. Mol. Liq. 213, 345-350 (2016)

124. Ozmen, M., Can, K., Arslan, G., Tor, A., Cengeloglu, Y., Ersoz, M.: Adsorption of $\mathrm{Cu}$ (II) from aqueous solution by using modified $\mathrm{Fe}_{3} \mathrm{O}_{4}$ magnetic nanoparticles. Desalination 254(1), 162-169 (2010)

125. Ge, F., Li, M.-M., Ye, H., Zhao, B.-X.: Effective removal of heavy metal ions $\mathrm{Cd}^{2+}, \mathrm{Zn}^{2+}, \mathrm{Pb}^{2+}, \mathrm{Cu}^{2+}$ from aqueous solution by polymer-modified magnetic nanoparticles. J. Hazard. Mater. 211, 366-372 (2012)

126. Wang, Z., Wu, D., Wu, G., Yang, N., Wu, A.: Modifying $\mathrm{Fe}_{3} \mathrm{O}_{4}$ microspheres with rhodamine hydrazide for selective detection and removal of $\mathrm{Hg}^{2+}$ ion in water. J. Hazard. Mater. 244, 621-627 (2013)

127. Warner, C.L., Addleman, R.S., Cinson, A.D., Droubay, T.C., Engelhard, M.H., Nash, M.A., Yantasee, W., Warner, M.G.: High-performance, superparamagnetic, nanoparticle-based heavy metal sorbents for removal of contaminants from natural waters. ChemSusChem 3(6), 749-757 (2010)

128. Ying-Ying, W., Zhen-Hu, X.: Multi-walled carbon nanotubes and powder-activated carbon adsorbents for the removal of nitrofurazone from aqueous solution. J. Dispers. Sci. Technol. 37(5), 613-624 (2016)
129. Shirmardi, M., Mahvi, A.H., Mesdaghinia, A., Nasseri, S., Nabizadeh, R.: Adsorption of acid red18 dye from aqueous solution using single-wall carbon nanotubes: kinetic and equilibrium. Desalination Water Treat. 51(34-36), 6507-6516 (2013)

130. Bazrafshan, E., Mostafapour, F.K., Hosseini, A.R., Raksh Khorshid, A., Mahvi, A.H.: Decolorisation of reactive red 120 dye by using single-walled carbon nanotubes in aqueous solutions. J. Chem. (2013). doi:10.1155/2013/938374

131. Dehghani, M.H., Taher, M.M., Bajpai, A.K., Heibati, B., Tyagi, I., Asif, M., Agarwal, S., Gupta, V.K.: Removal of noxious $\mathrm{Cr}(\mathrm{VI})$ ions using single-walled carbon nanotubes and multiwalled carbon nanotubes. Chem. Eng. J. 279, 344-352 (2015)

132. Selen, V., Güler, Ö., Özer, D., Evin, E.: Synthesized multi-walled carbon nanotubes as a potential adsorbent for the removal of methylene blue dye: kinetics, isotherms, and thermodynamics. Desalination Water Treat. 57(19), 8826-8838 (2016)

133. Zare, K., Sadegh, H., Shahryari-Ghoshekandi, R., Maazinejad, B., Ali, V., Tyagi, I., Agarwal, S., Gupta, V.K.: Enhanced removal of toxic Congo red dye using multi walled carbon nanotubes: kinetic, equilibrium studies and its comparison with other adsorbents. J. Mol. Liq. 212, 266-271 (2015)

134. Alkaim, A.F., Sadik, Z., Mahdi, D.K., Alshrefi, S.M., Al-Sammarraie, A.M., Alamgir, F.M., Singh, P.M., Aljeboree, A.M.: Preparation, structure and adsorption properties of synthesized multiwall carbon nanotubes for highly effective removal of maxilon blue dye. Korean J. Chem. Eng. 32(12), 2456-2462 (2015)

135. Vukovic, G.D., Marinkovic, A.D., Skapin, S.D., Ristic, M.Đ., Aleksic, R., Peric-Grujic, A.A., Uskokovic, P.S.: Removal of lead from water by amino modified multi-walled carbon nanotubes. Chem. Eng. J. 173(3), 855-865 (2011)

136. Ren, Y., Yan, N., Wen, Q., Fan, Z., Wei, T., Zhang, M., Ma, J.: Graphene $/ \delta-\mathrm{MnO}_{2}$ composite as adsorbent for the removal of nickel ions from wastewater. Chem. Eng. J. 175, 1-7 (2011)

137. Doong, R.-A., Chiang, L.-F.: Coupled removal of organic compounds and heavy metals by titanate/carbon nanotube composites. Water Sci. Technol. 58(10), 1985-1992 (2008)

138. Moussavi, G., Mahmoudi, M.: Removal of azo and anthraquinone reactive dyes from industrial wastewaters using $\mathrm{MgO}$ nanoparticles. J. Hazard. Mater. 168(2), 806-812 (2009)

139. Wang, H., Gao, H., Chen, M., Xu, X., Wang, X., Pan, C., Gao, J.: Microwave-assisted synthesis of reduced graphene oxide/titania nanocomposites as an adsorbent for methylene blue adsorption. Appl. Surf. Sci. 360, 840-848 (2016)

140. Liang, J., Liu, J., Yuan, X., Dong, H., Zeng, G., Wu, H., Wang, H., Liu, J., Hua, S., Zhang, S., Yu, Z., He, X., He, Y.: Facile synthesis of alumina-decorated multi-walled carbon nanotubes for simultaneous adsorption of cadmium ion and trichloroethylene. Chem. Eng. J. 273, 101-110 (2015)

141. Ni, Y., Jin, L., Zhang, L., Hong, J.: Honeycomb-like Ni@ C composite nanostructures: synthesis, properties and applications in the detection of glucose and the removal of heavy-metal ions. J. Mater. Chem. 20(31), 6430-6436 (2010)

142. Ghorbani, M., Eisazadeh, H., Ghoreyshi, A.: Removal of zinc ions from aqueous solution using polyaniline nanocomposite coated on rice husk. Iran. J. Energy Environ. 3(1), 83-88 (2012)

143. Bhaumik, M., Maity, A., Srinivasu, V., Onyango, M.S.: Enhanced removal of $\mathrm{Cr}(\mathrm{VI})$ from aqueous solution using polypyrrole/ $\mathrm{Fe}_{3} \mathrm{O}_{4}$ magnetic nanocomposite. J. Hazard. Mater. 190(1), 381-390 (2011)

144. Kumar, A., Sharma, G., Naushad, M., Singh, P., Kalia, S. Polyacrylamide/Ni0. 02Zn0. 980 nanocomposite with high solar light photocatalytic activity and efficient adsorption capacity for toxic dye removal. Ind. Eng. Chem. Fundam. 53(40), 15549-15560 (2014) 